\title{
Exciting Times: New Advances Towards Understanding the Regulation and Roles of Kainate Receptors
}

\author{
Ashley J. Evans ${ }^{1} \cdot$ Sonam Gurung ${ }^{1} \cdot$ Jeremy M. Henley ${ }^{1} \mathbb{D} \cdot$ Yasuko Nakamura $^{1} \cdot$ Kevin A. Wilkinson $^{1}$
}

Received: 23 August 2017 / Revised: 27 November 2017 / Accepted: 7 December 2017 / Published online: 21 December 2017

(c) The Author(s) 2017. This article is an open access publication

\begin{abstract}
Kainate receptors (KARs) are glutamate-gated ion channels that play fundamental roles in regulating neuronal excitability and network function in the brain. After being cloned in the 1990s, important progress has been made in understanding the mechanisms controlling the molecular and cellular properties of KARs, and the nature and extent of their regulation of wider neuronal activity. However, there have been significant recent advances towards understanding KAR trafficking through the secretory pathway, their precise synaptic positioning, and their roles in synaptic plasticity and disease. Here we provide an overview highlighting these new findings about the mechanisms controlling KARs and how KARs, in turn, regulate other proteins and pathways to influence synaptic function.
\end{abstract}

Keywords Kainate receptors · GluK2 $\cdot$ Trafficking $\cdot$ RUSH $\cdot$ Synaptic transmission $\cdot$ Synaptic plasticity

\section{Introduction}

Glutamate is the major excitatory neurotransmitter in the CNS and participates in nearly all aspects of brain function. There are three major subclasses of ionotropic glutamate receptors, kainate receptors (KARs), AMPA receptors and NMDA receptors. KARs are widely distributed throughout the brain and, depending on the cell type in question, they can be localised at pre-, post- and/or extrasynaptic sites. In general, presynaptic KARs modulate both excitatory and inhibitory neurotransmitter release, postsynaptic KARs contribute to excitatory neurotransmission and extrasynaptic KARs play a role in determining neuronal excitability (for reviews of KAR physiology see [1-4]). For reasons that remain unclear, compared to AMPARs and NMDARs, synaptic KAR ionotropic responses are highly restricted to subsets of excitatory synapses. For example, some neurons, including CA1 pyramidal neurons and dispersed hippocampal cultures display robust KAR currents following

Jeremy M. Henley

j.m.henley@bristol.ac.uk

$\bowtie$ Kevin A. Wilkinson

Kevin.Wilkinson@bristol.ac.uk

1 School of Biochemistry, Centre for Synaptic Plasticity, Biomedical Sciences Building, University of Bristol, Bristol BS8 1TD, UK kainate application [5, 6] but they lack synaptically-evoked ionotropic postsynaptic excitatory post-synaptic currents $\mathrm{KAR}_{\text {(EPSCs) }}$ [6-8]. Intriguingly, it has been proposed that $\mathrm{KAR}_{\text {(EPSCs) }}$ are present only at synapses that do not contain AMPAR $_{\text {(EPSCs) }}[9,10]$.

Remarkably, despite their classical ion channel structure, KARs can also signal via a non-canonical G-protein coupled metabotropic cascade [11]. In contrast, postsynaptic metabotropic KAR signalling is much more widespread than ionotropic KAR signalling [12,13] and recent discoveries have highlighted their previously unsuspected roles in neuromodulation. For example, they regulate inhibitory transmission by controlling surface expression of the chloride transporter KCC2 [14] and mediate certain forms of synaptic plasticity $[15,16]$. For extensive reviews of metabotropic KARs see $[4,17]$.

Our aim here is to provide an overview of recent advances in understanding the cellular regulation of KARs and their interacting proteins, and how these processes influence KAR-mediated synaptic transmission and plasticity. We highlight what is known, what remains to be established, and outline the future perspectives for KAR research and how it will impact on our understanding of brain function and dysfunction in disease. 


\section{Nomenclature of KAR Subunits}

Since their initial cloning $[18,19]$ the names of specific KAR subunits have changed to conform to a simpler, more systematic naming system. This can lead to considerable confusion in the field since many seminal early papers use the old nomenclature. Nonetheless, since 2009, the International Union of Basic and Clinical Pharmacology (IUPHAR) naming system has been almost universally adopted. Briefly, the subunits formerly most commonly referred to as GluR5, GluR6, GluR7, KA1 and KA2 are now named GluK1, GluK2, GluK3, GluK4 and GluK5, respectively, and the genes encoding these proteins are named GRIKI-5 [20].

\section{KARs from Birth to Maturity}

\section{KAR Structure and Assembly}

KARs are heteromeric assemblies containing four subunits. Each subunit has a large extracellular N-terminal domain (NTD), helical transmembrane domains (TMD) including three membrane spanning domains (M1, M3 and M4) and a membrane re-entrant domain (M2), and an intracellular C-terminal domain (CTD). The latter part of the NTD (the last $~ 150$ amino acids, S1) together with the extracellular loops between M3 and M4 (S2) form the ligand-binding domain (LBD) [21]. Recently, detailed structural information has been gained by solving the crystal structure of kainate receptor subunits and this is reviewed in detail elsewhere [22-25].

\section{Heteromeric Assembly}

Following protein synthesis, the NTDs initiate receptor assembly in the endoplasmic reticulum (ER) by facilitating dimer formation, and the dimerization of two dimers then leads to the formation of tetrameric receptors. Based on affinity for their ligand, KAR subunits have been grouped into low affinity (GluK1-3) and high affinity (GluK4-5) receptors. Studies on recombinant systems have shown that low affinity GluK1-3 subunits can form ion channels as both homomers and heteromers but high affinity GluK4 and GluK5 subunits can only form heteromeric functional ion channels when complexed with the low-affinity subunits $[19,26,27]$. The most abundant subunit combination in the brain comprises GluK2 and GluK5. This occurs, at least in part, because widely distributed contacts within the NTD of GluK2 and GluK5 favour the assembly of functional heteromeric receptors over homomeric receptors [28].

\section{Alternative Splicing}

Regions within the N- and C- terminal domains of KAR subunits can undergo alternative RNA splicing. For instance, the extracellular N-terminal domain of GluK1 can produce two variants, GluK1 $1_{1}$ and GluK1 $1_{2}$ [29], while the C-terminus has four splice variants, GluK1a, GluK1b, GluK1c and GluK1d [30, 31]. Splice variants have also been reported at the C-termini of both GluK2 and GluK3; GluK2a/GluK2b/ GluK2c and GluK3a/GluK3b, respectively [32-34]. C-terminal alternative splicing of KAR subunits has been shown to greatly affect the ability of receptors to exit the ER and accumulate at the cell surface. Furthermore, different C-termini facilitate distinct protein-protein interactions and it is likely they provide mechanisms for nuanced tuning of specific KARs at particular locations [35-37].

\section{RNA Editing}

In addition to splicing, further diversity arises from varying degrees of RNA editing in GluK1 and GluK2 subunits [38, 39]. For example, $Q / R$ editing in the pore-lining region of GluK2 results in a change from the genomically encoded glutamine residue to an arginine. This change alters the properties of the resultant KAR from calcium permeable to calcium impermeable and also alters the biophysical properties of the channel [40]. Furthermore, GluK2 Q/R editing reduces its ability to assemble with other subunits, leading to its accumulation as monomers and dimers that are retained in the ER [41].

It is well established that GluK1/GluK2 editing is developmentally controlled through regulation of the enzyme that also catalyses GluK1/2 RNA editing, ADAR2 [42-44]. For an excellent recent review see [45]. ADAR2 levels are low in embryonic brain and during development ADAR2 levels increase [46]. After birth 80\% of GluK2 and 40\% GluK1 are edited, which leads to fewer surface KARs and lower conductance and $\mathrm{Ca}^{2+}$ permeability [47]. Furthermore, recent evidence has suggested that the ADAR2 dependent $\mathrm{Q} / \mathrm{R}$ editing of GluK2 is also dynamically regulated during homeostatic scaling [48]. Suppression of synaptic activity with TTX results in upscaling of KAR surface expression, which is, at least in part, due to reduced $Q / R$ editing of GluK2 [48]. Therefore, this developmental and homeostatic regulation of GluK2 Q/R editing likely control processes such as synaptogenesis $[49,50]$, plasticity $[40]$ and pathology [47].

\section{KAR Trafficking Through the Secretory Pathway}

The accurate and timely delivery of KARs to specific pre-, post- and extrasynaptic locations is fundamental to many aspects of neuronal function. Most research efforts have 
focused on the processes of transcription, endocytosis, recycling and degradation (for reviews see $[4,51]$ ). However, after assembly, tetrameric KARs need to traffic through the secretory pathway to reach the cell surface and be appropriately targeted. Until recently, it was unknown whether these early KAR trafficking steps occur locally in dendrites and, importantly, how these processes are regulated.

\section{Local Dendritic Translation and Secretory Pathway Trafficking}

In neurons, mRNAs can be trafficked to distant sites in axons and dendrites for local translation and processing [52-57]. A range of neuronal transmembrane proteins, including AMPARs, NMDARs and $\mathrm{GABA}_{\mathrm{B}} \mathrm{Rs}$, can be translated using both somatic and dendritically localised ribosome patterned rough ER. They then traffic from the ER using dendritic ER exit sites and utilise the somatic Golgi or dendritic Golgi outposts for mature glycosylation [48, 58-62]. Importantly, all of the secretory pathway machinery appears to be present in neurites as iGluRs can mature in isolated dendrites [63]. For example, AMPAR mRNAs traffic into dendrites, under the control of synaptic activity, to create local utilizable pools of mRNA for local translation [64].
Recently, using the RUSH system, which allows the synchronous release and visualization of cargo proteins trafficking through the secretory pathway $[65,66]$, it has been demonstrated that GluK2-containing KARs utilise these local secretory pathway systems for their delivery to the cell surface [48] (Fig. 1). However, the functional consequences that result from KARs utilising these local secretory pathway systems remain to be established.

\section{Activity Dependent Secretory Pathway Trafficking}

Although there is a strong base of knowledge about the activity-dependent regulation of KAR endocytosis and recycling [13, 15, 67-71], compared to AMPARs [72] and tsVSVG cargo [73], little is known about the activitydependence of secretory pathway trafficking of KARs. A very recent study reported that secretory pathway KAR trafficking is indeed highly regulated in multiple different cellular activity contexts [48]. Activation of surface KARs results in a decrease in secretory pathway trafficking of de novo GluK2-containing KARs from the ER to the cell surface, demonstrating that KAR secretory pathway trafficking is subject to a negative feedback mechanism controlling KAR surface levels. Mechanistically, this pathway is dependent on the PDZ ligand of GluK2, since a mutant lacking this

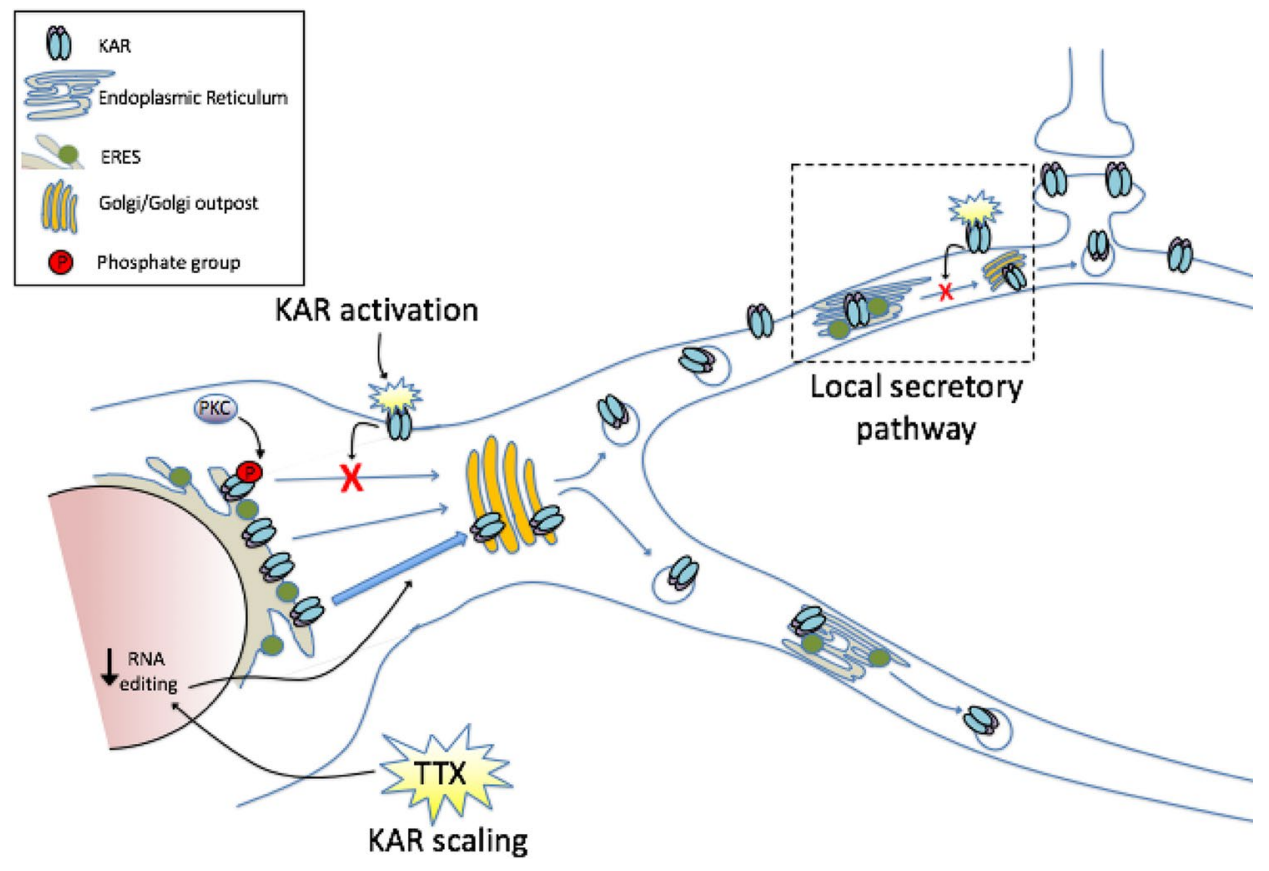

Fig. 1 Control of KAR trafficking through the secretory pathway. KAR trafficking is controlled at multiple levels under basal and activity-dependent conditions. PKC phosphorylation of the GluK2 subunit at S846 and S868 reduces ER exit of GluK2-containing receptors. Activation of surface KARs leads to a feedback mechanism that reduces forward trafficking of KARs from the ER, via a mechanism that requires the PDZ ligand of GluK2. Furthermore, induction of synaptic scaling via inhibiting neuronal activity with TTX leads to upscaling of KARs, at least in part via reduced RNA editing of the GluK2 subunit, favouring forward trafficking of GluK2-containing KARs. Finally, in addition to using somatic Golgi for post-ER processing, KARs can also use local secretory pathway systems in dendrites 
protein interaction site is insensitive to the effects of kainate on secretory pathway trafficking, however the GluK2 interacting partner responsible remains to be determined [48].

\section{Roles of GluK5 in Trafficking}

As well as interactions with the GluK2 subunit, interactions with GluK5 also determine flux through the secretory pathway. ER retention sequences in the C-terminus of GluK5 facilitate its interaction with the COPI coat complex, driving retrograde Golgi to ER trafficking of KARs, and acting as an ER retrieval mechanism [74]. This interaction is disrupted by the heteromerization of GluK2 with GluK5 and binding to $14-3-3 \zeta$, which promotes forward trafficking to the cell surface, both driving ER exit and favouring assembly of heteromeric KARs [74].

\section{Post-translational Modifications}

Further tight control of the ER exit and secretory pathway trafficking of KARs is also provided by post-translational modifications, most notably PKC phosphorylation of GluK2 at residues S846 and S868 [48, 75], which act to restrict forward trafficking of GluK2-containing KARs.

Thus, far from being a passive process, ER exit of KARs and flux through the secretory pathway is emerging as a major point of regulation in determining the surface expression of KARs under basal and activity-dependent conditions (summarised in Fig. 1).

\section{Synaptic Positioning and Function of KARs}

Given the highly-ordered targeting and localisation of KARs at distinct synaptic and sub-synaptic compartments, a key question in the field relates to how KARs are targeted to, and retained at, specific pre- or postsynaptic locations. While many of the factors that mediate this distribution are yet to be determined, as discussed below, recent data suggest that structural aspects of the receptor subunits, the presence of Neto auxiliary proteins in the KAR complex and the secreted C1q-like proteins play important roles in these processes (Fig. 2).

\section{Postsynaptic KARs}

\section{Role of the GluK2 C-Terminus in Synaptic Localisation}

In the cerebellum, KARs are located post-synaptically on cerebellar granule cells, which receive inputs from mossy fibres. These receptors comprise GluK2/5 and the auxiliary subunit Neto2 [76] (see below). Synaptic localisation of this complex is dependent on the GluK2 subunit, since ablation

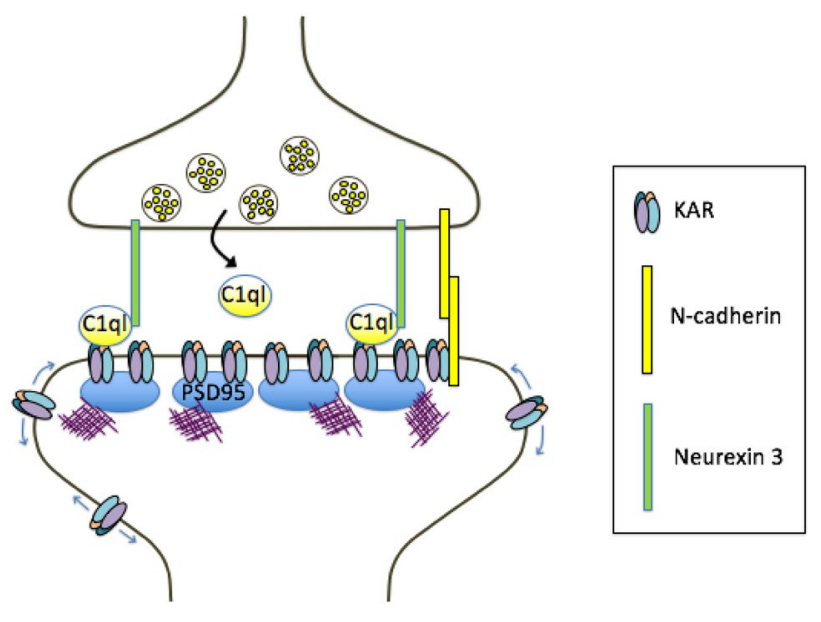

Fig. 2 Mechanisms of KAR synaptic localisation. At mossy fibreCA3 (MF-CA3) synapses, presynaptically released C1ql proteins cluster KARs through binding to KAR subunit extracellular domains, and forming a tripartite trans-synaptic complex with presynaptic neurexin 3. KAR synaptic incorporation is also promoted through interactions between the GluK2 C-terminus and the trans-synaptic adhesion molecule $\mathrm{N}$-cadherin, and through interactions between the C-termini of GluK1, GluK2 and GluK5 (and potentially Neto1) and PSD95

of GluK5 or Neto2 has no effect on levels of GluK2/Neto2 or GluK2/GluK5, respectively, in the postsynaptic density (PSD) fraction [76, 77]. Furthermore, knock-in mice in which the intracellular C-terminus of GluK2 is replaced with the C-terminus of the AMPAR subunit GluA1 do not exhibit synaptic KAR responses in cerebellar slices [77]. Notably, whole cell KAR currents were unaffected, demonstrating a specific role for the GluK2 C-terminus in synaptic incorporation of KARs at cerebellar synapses but not in receptor surface expression [77]. Furthermore, these mice show reduced postsynaptic KAR responses at MF-CA3 synapses in the hippocampus, the prototypical KAR-containing synapse in the brain, but no reduction in total KAR responses, again indicating a specific role for the GluK2 C-terminus in synaptic incorporation, but not surface expression, of KARs [77].

\section{Roles of GluK4 and GluK5 in the Synaptic Specificity of KARs}

While the C-terminus of GluK2 seems to be necessary for synaptic incorporation, synapse specificity in the hippocampus has been shown to be dependent on the GluK4 and GluK5 subunits. Postsynaptic KARs at MF-CA3 synapses are lost in mice lacking both of these subunits [78]. Moreover, in GluK $4 / 5^{-1-}$ mice there is a redistribution of GluK2 immunolabelling to more distal dendrites in CA3 pyramidal neurons [77], suggesting GluK4/5 are crucial determinants of the synapse specificity of KARs in the hippocampus. Interestingly, viral re-expression of GluK5 in the 
hippocampus of GluK4/5 $5^{-1-}$ mice rescued GluK2 signal in stratum lucidum, but this did not occur for a GluK5 chimera in which the extracellular $\mathrm{N}$-terminus was replaced with that of GluK2 [77], which the authors attribute to the ability of the N-terminus of GluK5 to bind to the mossy fibre-enriched C1q-like proteins (see below).

\section{Proteins that Interact with KARs to Define Postsynaptic Localisation}

\section{$\mathrm{N}$-Cadherin}

The fact that MF-CA3 synapses in GluK2 ${ }^{-/-}$mice lack postsynaptic KAR responses [79] has allowed examination of the factors required for their effective synaptic positioning by reexpressing wild-type or mutant GluK2 in CA3 neurons. The last 20 amino acids of GluK2 are required for KAR incorporation at MF-CA3 synapses [80] and this region mediates interactions between GluK2 and the neuronal cell adhesion molecule N-cadherin [81]. At MF-CA3 synapses in wildtype mice, expression of a dominant-negative $\mathrm{N}$-cadherin reduced KAR EPSCs, as did knockdown of N-cadherin mediated by expression of Cre recombinase in CA3 cells from $\mathrm{N}$-cadherin floxed mice [80]. Together, these findings demonstrate GluK2 binding to N-cadherin is a key determinant of GluK2 recruitment to MF-CA3 synapses.

\section{PSD95}

The synaptic scaffold protein PSD95 binds to the C-terminal PDZ ligands of the core KAR subunits GluK1, GluK2 and GluK5 [82, 83]. PSD95 also binds to the auxiliary subunit Neto1 [84], and accelerates the recovery of GluK2 from desensitisation [85]. The KAR component of the EPSC at MF-CA3 synapses is reduced in PSD95 knockout mice, suggesting a role for this interaction in KAR synaptic localisation [86]. However, whether this is due to direct binding of KARs to PSD95 and, if it is, which subunits are responsible, remains to be determined. Moreover, as discussed below, regulation of the interaction between GluK5 and PSD95 is required for long-term depression (LTD) of KARs at MF-CA3 synapses [87].

\section{C1ql}

The C1q-like proteins are a family of secreted synaptic organisers [88]. Two members of this family, C1q12 and C1q13, are highly expressed by hippocampal mossy fibres and contribute to the localisation of KARs to mossy fibre synapses in CA3 neurons [77, 89]. In heterologous cells, $\mathrm{C} 1 \mathrm{q} 12$ and 3 bind to the N-terminal domains of GluK2 and GluK4 [89], although another study instead observed binding to GluK5 [77]. C1q12 and 3 are present at MF-CA3 synapses, and their levels are reduced in slices from GluK2 $2^{-/}$or GluK4 ${ }^{-/}$mice, suggesting GluK2 and GluK4 act as binding sites for C1q12/3 [89]. Moreover, GluK2/3 immunoreactivity is markedly decreased in CA3 stratum lucidum in C1q12/3 knockout mice, and KAR EPSCs at MF-CA3 synapses are reduced to levels similar to those observed in GluK2 $2^{-1-}$ mice. The presynaptic adhesion molecule neurexin 3 binds to secreted C1q12/3 and a neurexin 3-C1ql-KAR complex was isolated in co-cultures of HEK293 cells expressing neurexin 3 and C1q12/3 and neurons [89]. Thus, specific secretion of C1ql proteins at mossy fibres provides the basis for a trans-synaptic complex that clusters KARs postsynaptically at MF-CA3 synapses (Fig. 2).

\section{Neto1 and Neto2}

Neto1 and Neto2 are single pass transmembrane proteins that associate with KAR complexes through binding to the GluK1-3 subunits [90, 91]. Neto1 is expressed abundantly in the hippocampus and is a component of postsynaptic KARs at MF-CA3 synapses [91] whereas Neto2 is more highly expressed in the cerebellum [90]. The effects of Neto proteins on KAR channel properties have been studied extensively (reviewed in [92-95]), but, briefly, Neto proteins generally slow the deactivation kinetics of KARs, which accounts for their different properties in vivo compared to exogenously expressed KARs in cell lines that do not contain Netos. Furthermore, it has also recently been shown that Neto proteins control the function of both somatodendritic and presynaptic KARs in somatostatin, cholecystokinin/cannabinoid receptor 1 , and parvalbumin-containing interneurons to regulate neuronal network inhibition [96]. However, as outlined below, how Neto proteins affect the trafficking and synaptic incorporation of KARs is less well established with the current literature containing apparently contradictory results.

\section{Netos and GluK2}

Initial studies observed no effect of Neto1 or Neto2 in mediating surface expression of GluK2 in heterologous systems $[90,91]$ nor any effects on the abundance of GluK2 or GluK5 in PSD fractions from Neto1 knockout mice [91]. Furthermore, co-expression of Neto1 or Neto2 did not enhance exogenous KAR responses in CA1 pyramidal neurons, which normally lack postsynaptic KAR EPSCs, arguing against a role for Netos in synaptic incorporation of GluK2-containing KARs [9]. Other studies, however, reported a reduction in synaptic GluK2 in the hippocampus of Neto1 knockout mice [97, 98], and from cerebellar PSD fractions from Neto2 knockout mice [99], supporting a role for Neto proteins in the synaptic targeting of GluK2. 
Moreover, recent studies have reported that Neto1 and Neto2 enhance GluK2 surface expression in HEK293 cells [100] and that injection of Neto 2 with GluK2 into oocytes potentiates GluK2 surface expression [77]. Given these apparently contradictory results, the precise roles of Neto proteins in the trafficking and targeting of GluK2-containing KARs remains to be defined.

\section{Netos and GluK1}

Neto proteins have also been reported to be involved in the trafficking of GluK1-containing KARs. Transfection of Neto2 with GluK1 promotes GluK1 surface expression in both COS-7 cells and cultured hippocampal neurons, and drives the synaptic incorporation of GluK1-containing KARs [101]. Consistent with this role, co-transfection of either Neto1 or Neto 2 with GluK1 in CA1 pyramidal cells in hippocampal slice cultures enhances GluK1 surface expression and synaptic targeting [9, 102]. It should be noted, however, that since these studies rely on overexpression of KAR subunits in cells that do not usually express GluK1 [6, 103] or exhibit synaptic KAR responses [6-8], the relevance of Neto proteins to GluK1 trafficking in vivo requires further examination.

Overall, although there is not yet a clear consensus, accumulating evidence suggests Neto proteins do influence surface expression and synaptic targeting of KARs under some circumstances. The apparently conflicting data regarding the roles of Netos in KAR trafficking and synaptic positioning can, at least in part, be attributed to the use of different model systems, clonal cell lines and neuronal subtypes, and experimental conditions. Thus, the current inconsistencies may reflect a complex relationship between
Netos and KARs, which can be affected differential subunit expression and the availability of cell type-specific interacting proteins. Moreover, GluK2 is subject to multiple, coordinated post-translational modifications (PTMs) including phosphorylation [75], SUMOylation [67, 69], ubiquitination [104, 105] and palmitoylation [71, 106], each of which could potentially directly or indirectly influence the actions of Netos. Clearly, further work is required to will determine the molecular mechanisms, under what circumstances, and for which subunit combinations Netos regulate KAR trafficking and targeting in vivo.

\section{KAR Post-translational Modifications and Post-synaptic Localisation}

\section{CaMKII Phosphorylation of GluK5}

LTD of KARs at MF-CA3 synapses is induced by a spike timing-, $\mathrm{Ca}^{2+}$ influx-, and CaMKII-dependent plasticity mechanism, which is absent in slices from GluK5 $5^{-1-}$ mice [87]. CaMKII phosphorylates the C-terminal domain of GluK5 in vitro and a phosphomimetic mutation enhances surface expression, but reduces synaptic localisation, in neurons. GluK5 phosphorylation enhances lateral mobility and reduces the interaction between GluK5 and PSD95. Moreover, while re-expression of GluK5 in GluK5 ${ }^{-1-}$ slices restored KAR-LTD, expression of a non-phosphorylatable GluK5 did not, demonstrating that direct phosphorylation of GluK5 by CaMKII is required for this form of KAR LTD [87]. Thus, these data indicate that CaMKII phosphorylation of GluK5-containing KARs regulates their synaptic localisation by antagonising the interaction between GluK5 and PSD95 (Fig. 3).
Fig. 3 Mechanisms of KAR-LTD. a At MF-CA3 synapses, LTD induction leads to CaMKII-mediated phosphorylation of the GluK5 subunit, reducing its ability to bind PSD95. This reduced anchoring of GluK5-containing KARs promotes their lateral mobility and diffusion away from the postsynapse, resulting in LTD of KAR EPSCs. b An alternative LTD mechanism results in PKC-dependent phosphorylation (not shown) and subsequent SUMOylation of the GluK2 subunit. This then leads to endocytosis of GluK2-containing KARs and LTD of KAR-mediated synaptic transmission
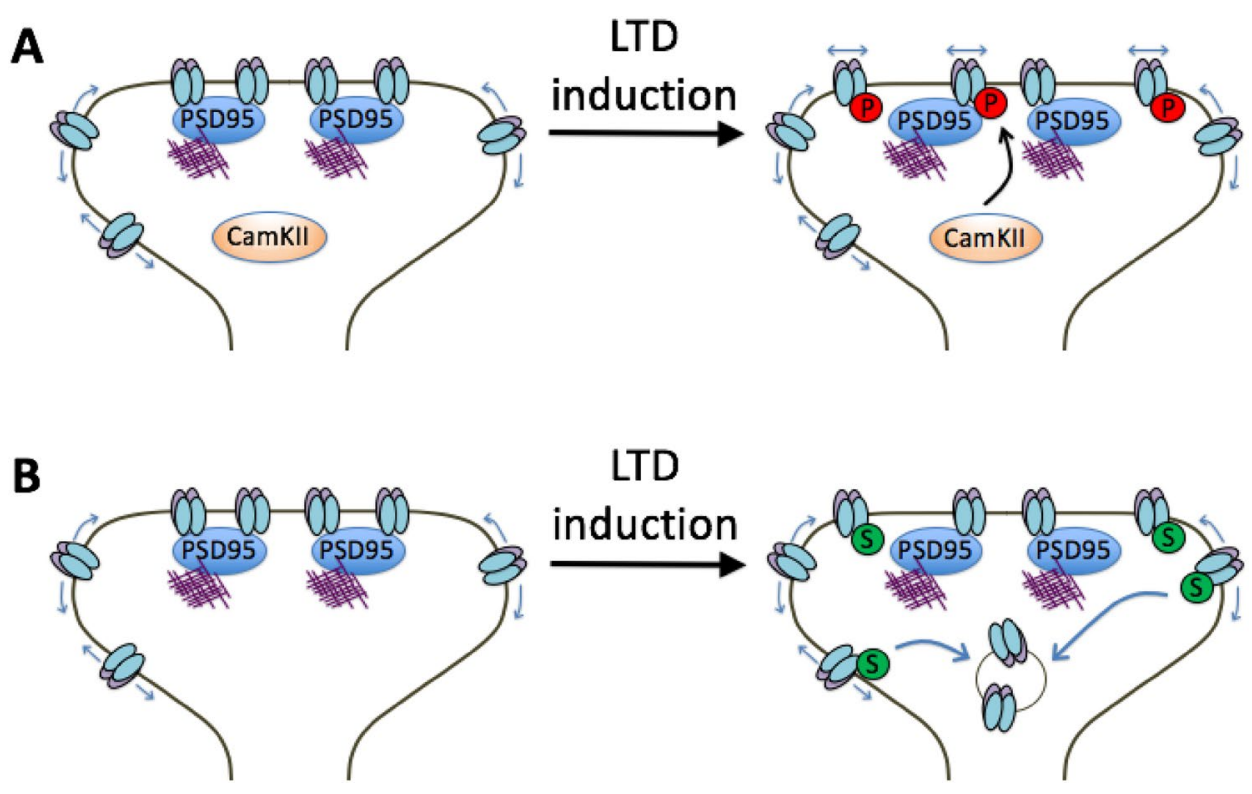


\section{PKC Phosphorylation of GluK2}

PKC phosphorylation of GluK2 at S846 and S868 regulates the surface expression of GluK2-containing KARs at several levels. It affects both GluK2 transit through the secretory pathway $[48,75]$ and KAR endocytosis and recycling back to the plasma membrane $[15,75]$. Phosphorylation of S846 promotes basal internalisation of GluK2-containing KARs in both HeLa cells and neurons [75], potentially via regulating the interaction between GluK2 and 4.1 proteins [71]. Furthermore, phosphorylation of both sites occurs in response to kainate stimulation of cultured neurons, and phosphorylation at S868 is required for agonist-induced endocytosis of GluK2, by promoting SUMOylation at lysine $886[15,69$, 107] (see below). It should be noted, however, that PKC phosphorylation of S868 also appears to be involved in recycling of endocytosed GluK2 back to the plasma membrane [15], suggesting that whether phosphorylation of S868 promotes insertion or removal of GluK2 from the plasma membrane is likely to be context-dependent.

\section{SUMOylation}

SUMOylation is a post-translational modification that results from the conjugation of a member of the $\sim 11 \mathrm{kD}$ SUMO family to lysine residues in substrate proteins [108]. GluK2 is SUMOylated at a single lysine residue in its intracellular C-terminus, K886, resulting in agonist-induced internalisation of GluK2-containing KARs [67]. Infusion of the catalytic domain of the deSUMOylating enzyme SENP1 increases KAR currents at MF-CA3 synapses, highlighting SUMOylaton as an endogenous regulator of the number of synaptic KARs [67]. Subsequent studies have demonstrated that SUMOylation of GluK2 is enhanced by prior PKCmediated phosphorylation of serine 868 and is required for LTD of kainate receptors at MF-CA3 synapses [15, 69].

\section{Ubiquitination}

One major functions of protein ubiquitination is to target proteins for lysosomal or proteasomal degradation [109]. A recent study identified that the Parkinson's diseaseassociated ubiquitin ligase Parkin directly interacts with and ubiquitinates the C-terminus of GluK2 [105]. Parkin ubiquitinates GluK2 in both heterologous cells and cultured neurons, and knockdown of Parkin increased GluK2 surface expression and increased vulnerability of hippocampal neurons to kainate-induced excitotoxicity. Furthermore, in a mouse model of autosomal recessive juvenile Parkinson's expressing a truncated form of Parkin, there are increased levels of GluK2 in substantia nigra and corresponding increases in cortex samples from human patients expressing mutations in Parkin [105]. Thus, GluK2 is a Parkin target that may contribute to the excitotoxic cell death of substantia nigra neurons in Parkinson's disease.

\section{KARs in Plasticity}

KARs are involved in both excitatory and inhibitory neurotransmission, controlling both short and longer-term plasticity. These properties have been extensively reviewed [2, 11] and we confine our discussion largely to the most recent findings relating to the role of postsynaptic KARs as inducers of long-term plasticity.

\section{KAR Regulation of Excitatory Neurotransmission}

Presynaptic KARs decrease glutamate release at CA3-CA1 pyramidal cell synapses [110-112]. Intriguingly, however, KARs have also been shown to facilitate glutamate release upon application of nanomolar concentrations of kainate. This facilitation of glutamate release requires KAR activation resulting in the accumulation of presynaptic calcium, the production of $\mathrm{Ca}^{2+}$-calmodulin complexes and the activation adenylate cyclase and PKA [113-115]. Thus, at certain synapses, KARs can exert bidirectional modulatory actions on glutamate release related to the extent of their activation (for recent review see [3]).

Postsynaptic KARs at MF-CA3 synapses undergo plastic changes, and exhibit several forms of LTD that can be induced by different stimulation protocols [15, 87]. Chamberlain et al. showed that SUMOylation of GluK2 is required for activity-dependent long-term depression of kainate receptor-mediated synaptic transmission (KAR LTD). They We further demonstrated that a critical trigger for SUMOylation is GluK2 phosphorylation by protein kinase $\mathrm{C}(\mathrm{PKC})$ and that this sequence of events is required for KAR LTD and that SUMOylation can act as the switch between enhanced or decreased surface expression of KARs after PKC phosphorylation [15].

Furthermore, in cultured neurons, activity-dependent up- or down-regulation of surface KARs can be induced by differential agonist application protocols $[13,68]$. KAR surface expression is also subject to homeostatic plasticity and can be 'scaled' by manipulating neuronal excitability [48]. Intriguingly, beyond being regulated by plasticity themselves, there is a growing appreciation that KARs also function as postsynaptic inducers of synaptic plasticity (Fig. 3).

Recently, a novel form of AMPAR-LTP was discovered at CA3-CA1 synapses that is mediated by activation of postsynaptic KARs (KAR-LTP AMPAR $_{\text {[16]). Despite the fact }}$ that CA1 pyramidal cells exhibit essentially no postsynaptic KAR EPSCs [6, 8, 9, 102, 116], activation of postsynaptic KARs by high-frequency stimulation of Schaffer collaterals inhibits a slow after-hyperpolarization current that regulates 
excitability in hippocampus (IsAHP) through a metabotropic cascade $[117,118]$, suggesting receptors are postsynaptically localised. Remarkably, however, at these synapses, KARs, which have a classical ion channel structure, signal primarily through a $\mathrm{G}$ protein-dependent pathway (for review see [17]).

Consistent with this, stimulation protocols that activate postsynaptic KARs on CA1 neurons induce LTP of AMPARs via a metabotropic signalling pathway [16]. GluK2 ${ }^{-/-}$mice lack this novel form of plasticity, indicating an absolute requirement for this subunit in induction of KAR-LTP $_{\text {AMPAR }}$ (Fig. 4). Similar to inhibition of IsAHP, KAR-LTP $_{\text {AMPAR }}$ is mediated by activation of pertussis toxin-sensitive G-proteins, and requires activation of PKC and PLC. Furthermore, similar to LTP induced by activation

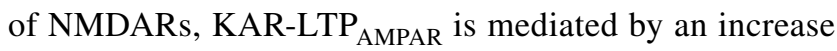
in surface AMPARs supplied by recruitment of recycling endosomes to spines and also leads to structural plasticity, as determined by an increase in spine size and maturation [16].

Thus, although the exact mechanisms are still to be determined, it is clear that KAR metabotropic signalling plays a key role in directly mediating certain forms of AMPARmediated plasticity at CA1 synapses.

\section{KAR Regulation of Inhibitory Neurotransmission}

\section{KAR Regulation of GABA Release}

An important facet of KAR physiology is that they coordinate and regulate neuronal and network activity via regulation of both excitatory and inhibitory transmission. Presynaptic KARs downregulate GABA release from interneurons in the hippocampus through a metabotropic PKC and PLC

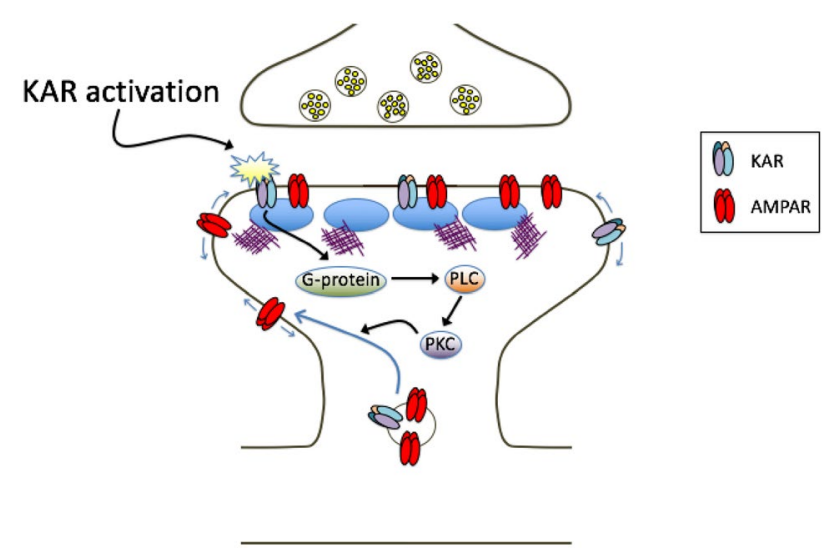

Fig. 4 Mechanism of KAR-LTP ${ }_{\text {AMPAR }}$. At CA3-CA1 synapses, activation of postsynaptic KARs leads to LTP of AMPAR-mediated synaptic transmission. This occurs through KAR-mediated activation of a pertussis toxin-sensitive $\mathrm{G}$ protein, activation of phospholipase $\mathrm{C}$ (PLC), PKC, and increased exocytosis of AMPARs from recycling endosomes dependent pathway that reduces inhibitory postsynaptic currents (IPSCs) [119].

\section{KARs and $G A B A_{A} R s$}

Moreover, postsynaptic KAR metabotropic signalling depresses synaptic $\mathrm{GABA}_{\mathrm{A}} \mathrm{Rs}$ while at the same time potentiating extrasynaptic $\mathrm{GABA}_{\mathrm{A}} \mathrm{Rs}$, in a process that decreases synaptic inhibitory drive to facilitate synaptic plasticity, while simultaneously protecting against neuronal over-excitation by promoting extrasynaptic inhibition [120].

\section{KARs and KCC2}

In addition to this direct effect on $\mathrm{GABA}_{\mathrm{A}} \mathrm{R}$-mediated transmission, KARs separately regulate the potassium-chloride cotransporter KCC2. KCC2 is crucial because it establishes the electrochemical chloride gradient for postsynaptic inhibition through $\mathrm{GABA}_{\mathrm{A}} \mathrm{Rs}[121,122]$ and its dysregulation is implicated in autism spectrum disorder (ASD; [123]) and epilepsy [124]. KCC2 interacts with both Neto2 [125] and GluK2 [126], which increase the total abundance and enhance surface expression of KCC2 [14]. KCC2 and GluK2 form macromolecular assemblies that traffic together, and this complex regulates intraneuronal chloride homeostasis to support $\mathrm{GABA}_{\mathrm{A}} \mathrm{R}$-mediated transmission [126]. In addition, this process is further controlled by phosphorylation of serines 846 and 868 in GluK2 to determine surface KCC2 levels [14]. These findings establish clear roles for KARs as modulators of postsynaptic inhibitory transmission.

\section{KARs in Disease}

Dysregulation of common molecular pathways underlies multiple neurological and neurodegenerative diseases and there is mounting evidence that KAR dysfunction could be one such feature (reviewed in [127, 128]).

\section{Epilepsy}

KAR dysfunction is particularly closely associated with temporal lobe epilepsy (TLE) [129], and GluK2 $2^{-/-}$mice exhibit significantly fewer seizures than wild-type counterparts [79]. TLE is associated with abnormal sprouting of recurrent mossy fibres, which synapse onto dentate gyrus cells [130-132] and this abnormal sprouting is also reduced in GluK2 ${ }^{-1-}$ mice [133]. Consistent with the requirement for recruitment of KARs to postsynaptic sites for seizure activity, despite induction of MF sprouting in an animal model of TLE, C1q12/3 double KO mice are resistant to seizures [89] and genetic silencing of KARs at CA3 synapses attenuates kainate-induced seizures [134]. Together, these 
studies suggest that recurrent synaptic activity, mediated by postsynaptic KARs, drives seizure activity in TLE, and highlights KARs as an attractive therapeutic target in the treatment of this disorder.

\section{KARs and Other Neurological Disorders}

In addition to TLE, both gain [135] and loss [136, 137] of GluK2 have been reported to lead to ASD-like phenotypes. Furthermore, duplication of the GluK4 gene has been associated with autism [138] and, consistent with this, overexpression of GluK4 in the forebrain of mice causes severe anxiety and ASD-like behaviours [139]. Additionally, GluK4 has been linked with treatment-resistant depression [140], and disruption of the gene encoding GluK4 has been observed in a patient with schizophrenia and mental retardation [141].

Most recently it has been reported that complete ablation of all KAR subunits results in disrupted corticostriatal function and dramatic obsessive-compulsive-like behaviour with severe self-grooming [142]. Together with the previous studies, these new observations support the notion that KARmediated control of network activity is a key determinant of higher brain function, and that disruption of these pathways can lead to multiple neurological disorders.

\section{Perspectives}

Although historically much less studied than AMPARs or NMDARs, there is a currently a renaissance in KAR research fuelled by the realisation that they are multifunctional neuronal modulators that have roles in health and disease far beyond those previously appreciated.

To understand how KARs exert these regulatory effects, it is necessary to define how KARs themselves are controlled and how they interact with, and regulate, other proteins and systems. Furthermore, while there is a growing appreciation of the multifaceted roles played by KARs, a number of fundamental questions remain unanswered. For example, while it is widely-accepted that KARs can signal both ionotropically and metabotropically through G-proteins, how this dual signaling occurs, and what determines which 'mode' of signaling an individual KAR complex utilizes remains almost entirely unexplored. In addition, while we are beginning to understand the molecular events that control the specific distribution and synaptic localization of KARs, how these mechanisms cooperate to orchestrate the highly selective distribution of KARs in the brain remains an important unanswered question. Finally, although KARs can induce plasticity of AMPARs, exactly how this occurs, how widespread this form of plasticity is in the brain, and whether postsynaptic KARs can direct other forms of bidirectional synaptic plasticity remain unknown.
We expect that further studies examining how KAR localisation and signalling at pre- and postsynaptic sites impacts on neuronal function will answer many of these remaining questions, and will transform our understanding of the roles KARs play in development, plasticity and disease.

Open Access This article is distributed under the terms of the Creative Commons Attribution 4.0 International License (http://creativecommons.org/licenses/by/4.0/), which permits unrestricted use, distribution, and reproduction in any medium, provided you give appropriate credit to the original author(s) and the source, provide a link to the Creative Commons license, and indicate if changes were made.

\section{References}

1. Sihra TS, Flores G, Rodriguez-Moreno A (2014) Kainate receptors: multiple roles in neuronal plasticity. Neuroscientist 20:29-43

2. Carta M, Fievre S, Gorlewicz A, Mulle C (2014) Kainate receptors in the hippocampus. Eur J Neurosci 39:1835-1844

3. Sihra TS, Rodriguez-Moreno A (2013) Presynaptic kainate receptor-mediated bidirectional modulatory actions: mechanisms. Neurochem Int 62:982-987

4. Lerma J, Marques JM (2013) Kainate receptors in health and disease. Neuron 80:292-311

5. Ruano D, Lambolez B, Rossier J, Paternain AV, Lerma J (1995) Kainate receptor subunits expressed in single cultured hippocampal neurons: molecular and functional variants by RNA editing. Neuron 14:1009-1017

6. Bureau I, Bischoff S, Heinemann SF, Mulle C (1999) Kainate receptor-mediated responses in the CA1 field of wild-type and GluR6-deficient mice. J Neurosci 19:653-663

7. Castillo PE, Malenka RC, Nicoll RA (1997) Kainate receptors mediate a slow postsynaptic current in hippocampal CA3 neurons. Nature 388:182-186

8. Granger AJ, Shi Y, Lu W, Cerpas M, Nicoll RA (2013) LTP requires a reserve pool of glutamate receptors independent of subunit type. Nature 493:495-500

9. Sheng N, Shi YS, Lomash RM, Roche KW, Nicoll RA (2015) Neto auxiliary proteins control both the trafficking and biophysical properties of the kainate receptor GluK1. eLife 4:e11682

10. Sheng N, Shi YS, Nicoll RA (2017) Amino-terminal domains of kainate receptors determine the differential dependence on Neto auxiliary subunits for trafficking. Proc Natl Acad Sci USA 114:1159-1164

11. Lerma J (2003) Roles and rules of kainate receptors in synaptic transmission. Nat Rev Neurosci 4:481-495

12. Lourenco J, Matias I, Marsicano G, Mulle C (2011) Pharmacological activation of kainate receptors drives endocannabinoid mobilization. J Neurosci 31:3243-3248

13. Gonzalez-Gonzalez IM, Henley JM (2013) Postsynaptic kainate receptor recycling and surface expression are regulated by metabotropic autoreceptor signalling. Traffic 14:810-822

14. Pressey JC, Mahadevan V, Khademullah CS, Dargaei Z, Chevrier J, Ye W, Huang M, Chauhan AK, Meas SJ, Uvarov P, Airaksinen MS, Woodin MA (2017) A kainate receptor subunit promotes the recycling of the neuron-specific $\mathrm{K}^{+}-\mathrm{Cl}^{-}$co-transporter $\mathrm{KCC} 2$ in hippocampal neurons. J Biol Chem 292:6190-6201

15. Chamberlain SE, Gonzalez-Gonzalez IM, Wilkinson KA, Konopacki FA, Kantamneni S, Henley JM, Mellor JR (2012) SUMOylation and phosphorylation of GluK2 regulate 
kainate receptor trafficking and synaptic plasticity. Nat Neurosci $15: 845-852$

16. Petrovic MM, Viana da Silva S, Clement JP, Vyklicky L, Mulle C, Gonzalez-Gonzalez IM, Henley JM (2017) Metabotropic action of postsynaptic kainate receptors triggers hippocampal long-term potentiation. Nat Neurosci 20:529-539

17. Valbuena S, Lerma J (2016) Non-canonical signaling, the hidden life of ligand-gated ion channels. Neuron 92:316-329

18. Bettler B, Boulter J, Hermans-Borgmeyer I, O'Shea-Greenfield A, Deneris ES, Moll C, Borgmeyer U, Hollmann M, Heinemann S (1990) Cloning of a novel glutamate receptor subunit, GluR5: expression in the nervous system during development. Neuron 5:583-595

19. Egebjerg J, Bettler B, Hermans-Borgmeyer I, Heinemann S (1991) Cloning of a cDNA for a glutamate receptor subunit activated by kainate but not AMPA. Nature 351:745-748

20. Collingridge GL, Olsen RW, Peters J, Spedding M (2009) A nomenclature for ligand-gated ion channels. Neuropharmacology $56: 2-5$

21. Hughes TE (1994) Transmembrane topology of the glutamate receptors. A tale of novel twists and turns. J Mol Neurosci 5:211-217

22. Karakas E, Regan MC, Furukawa H (2015) Emerging structural insights into the function of ionotropic glutamate receptors. Trends Biochem Sci 40:328-337

23. Mollerud S, Frydenvang K, Pickering DS, Kastrup JS (2017) Lessons from crystal structures of kainate receptors. Neuropharmacology 112:16-28

24. Zhu S, Gouaux E (2017) Structure and symmetry inform gating principles of ionotropic glutamate receptors. Neuropharmacology 112:11-15

25. Meyerson JR, Chittori S, Merk A, Rao P, Han TH, Serpe M, Mayer ML, Subramaniam S (2016) Structural basis of kainate subtype glutamate receptor desensitization. Nature 537:567-571

26. Werner P, Voigt M, Keinanen K, Wisden W, Seeburg PH (1991) Cloning of a putative high-affinity kainate receptor expressed predominantly in hippocampal CA3 cells. Nature 351:742-744

27. Herb A, Burnashev N, Werner P, Sakmann B, Wisden W, Seeburg PH (1992) The KA-2 subunit of excitatory amino acid receptors shows widespread expression in brain and forms ion channels with distantly related subunits. Neuron 8:775-785

28. Kumar J, Schuck P, Mayer ML (2011) Structure and assembly mechanism for heteromeric kainate receptors. Neuron 71:319-331

29. Bettler B, Boulter J, Hermansborgmeyer I, Osheagreenfield A, Deneris ES, Moll C, Borgmeyer U, Hollmann M, Heinemann S (1990) Cloning of a novel glutamate receptor subunit, GluR5expression in the nervous system during development. Neuron 5:583-595

30. Sommer B, Burnashev N, Verdoorn TA, Keinanen K, Sakmann B, Seeburg PH (1992) A glutamate receptor channel with high affinity for domoate and kainate. EMBO J 11:1651-1656

31. Pinheiro P, Mulle C (2006) Kainate receptors. Cell Tissue Res 326:457-482

32. Schiffer HH, Swanson GT, Heinemann SF (1997) Rat GluR7 and a corboxy terminal splice variant, GluR7b, are functional kainate receptor subunits with a low sensitivity to glutamate. Neuron 19:1141-1146

33. Jaskolski F, Coussen F, Nagarajan N, Normand E, Rosenmund C, Mulle C (2004) Subunit composition and alternative splicing regulate membrane delivery of kainate receptors. J Neurosci 24:2506-2515

34. Pahl S, Tapken D, Haering SC, Hollmann M (2014) Trafficking of kainate receptors. Membranes 4:565-595
35. Ren Z, Riley NJ, Needleman LA, Sanders JM, Swanson GT, Marshall J (2003) Cell surface expression of GluR5 kainate receptors is regulated by an endoplasmic reticulum retention signal. $\mathrm{J}$ Biol Chem 278:52700-52709

36. Coussen F, Perrais D, Jaskolski F, Sachidhanandam S, Normand E, Bockaert J, Marin P, Mulle C (2005) Co-assembly of two GluR6 kainate receptor splice variants within a functional protein complex. Neuron 47:555-566

37. Jaskolski F, Normand E, Mulle C, Coussen F (2005) Differential trafficking of GluR7 kainate receptor subunit splice variants. J Biol Chem 280:22968-22976

38. Egebjerg J, Kukekov V, Heinemann SF (1994) Intron sequence directs RNA editing of the glutamate receptor subunit GluR2 coding sequence. Proc Natl Acad Sci USA 91:10270-10274

39. Howe JR (1996) Homomeric and heteromeric ion channels formed from the kainate type subunits GluR6 and KA2 have very small, but different unitary conductances. J Neurophysiol 76:510-519

40. Vissel B, Royle GA, Christie BR, Schiffer HH, Ghetti A, Tritto T, Perez-Otano I, Radcliffe RA, Seamans J, Sejnowski T, Wehner JM, Collins AC, O'Gorman S, Heinemann SF (2001) The role of RNA editing of kainate receptors in synaptic plasticity and seizures. Neuron 29:217-227

41. Ball SM, Atlason PT, Shittu-Balogun OO, Molnar E (2010) Assembly and intracellular distribution of kainate receptors is determined by RNA editing and subunit composition. J Neurochem 114:1805-1818

42. Bernard A, Khrestchatisky M (1994) Assessing the extent of RNA editing in the TMII regions of Glur5 and Glur6 kainate receptors during rat brain development. J Neurochem 62:2057-2060

43. Schmitt J, Dux E, Gissel C, Paschen W (1996) Regional analysis of developmental changes in the extent of GluR6 mRNA editing in rat brain. Brain Res Dev Brain Res 91:153-157

44. Bernard A, Ferhat L, Dessi F, Charton G, Represa A, Ben-Ari Y, Khrestchatisky M (1999) Q/R editing of the rat GluR5 and GluR6 kainate receptors in vivo and in vitro: evidence for independent developmental, pathological and cellular regulation. Eur J Neurosci 11:604-616

45. Nishikura K (2016) A-to-I editing of coding and non-coding RNAs by ADARs. Nat Rev Mol Cell Biol 17:83-96

46. Behm M, Wahlstedt H, Widmark A, Eriksson M, Ohman M (2017) Accumulation of nuclear ADAR2 regulates adenosineto-inosine RNA editing during neuronal development. J Cell Sci 130:745-753

47. Filippini A, Bonini D, La Via L, Barbon A (2016) The good and the bad of glutamate receptor RNA editing. Mol Neurobiol

48. Evans AJ, Gurung S, Wilkinson KA, Stephens DJ, Henley JM (2017) Assembly, secretory pathway trafficking, and surface delivery of kainate receptors is regulated by neuronal activity. Cell Rep 19:2613-2626

49. Tashiro A, Dunaevsky A, Blazeski R, Mason CA, Yuste R (2003) Bidirectional regulation of hippocampal mossy fiber filopodial motility by kainate receptors. A two-step model of synaptogenesis. Neuron 38:773-784

50. Sakha P, Vesikansa A, Orav E, Heikkinen J, Kukko-Lukjanov TK, Shintyapina A, Franssila S, Jokinen V, Huttunen HJ, Lauri SE (2016) Axonal kainate receptors modulate the strength of efferent connectivity by regulating presynaptic differentiation. Front Cell Neurosci. https://doi.org/10.3389/fncel.2016.00003

51. Contractor A, Mulle C, Swanson GT (2011) Kainate receptors coming of age: milestones of two decades of research. Trends Neurosci 34:154-163

52. Bramham CR, Wells DG (2007) Dendritic mRNA: transport, translation and function. Nat Rev Neurosci 8:776-789 
53. Doyle M, Kiebler MA (2011) Mechanisms of dendritic mRNA transport and its role in synaptic tagging. EMBO J 30:3540-3552

54. Holt CE, Schuman EM (2013) The central dogma decentralized: new perspectives on RNA function and local translation in neurons. Neuron 80:648-657

55. Ho VM, Dallalzadeh LO, Karathanasis N, Keles MF, Vangala S, Grogan T, Poirazi P, Martin KC (2014) GluA2 mRNA distribution and regulation by miR-124 in hippocampal neurons. Mol Cell Neurosci 61:1-12

56. Buxbaum AR, Yoon YJ, Singer RH, Park HY (2015) Singlemolecule insights into mRNA dynamics in neurons. Trends Cell Biol 25:468-475

57. Rangaraju V, Tom Dieck S, Schuman EM (2017) Local translation in neuronal compartments: how local is local? EMBO Rep 18:693-711

58. Horton AC, Ehlers MD (2004) Secretory trafficking in neuronal dendrites. Nat Cell Biol 6:585-591

59. Cui-Wang T, Hanus C, Cui T, Helton T, Bourne J, Watson D, Harris KM, Ehlers MD (2012) Local zones of endoplasmic reticulum complexity confine cargo in neuronal dendrites. Cell 148:309-321

60. Quassollo G, Wojnacki J, Salas DA, Gastaldi L, Marzolo MP, Conde C, Bisbal M, Couve A, Caceres A (2015) A RhoA signaling pathway regulates dendritic golgi outpost formation. Curr Biol 25:971-982

61. Valenzuela JI, Perez F (2015) Diversifying the secretory routes in neurons. Front Neurosci 9:358

62. Hanus C, Geptin H, Tushev G, Garg S, Alvarez-Castelao B, Sambandan S, Kochen L, Hafner AS, Langer JD, Schuman EM (2016) Unconventional secretory processing diversifies neuronal ion channel properties. eLife 5, e20609

63. Kacharmina JE, Job C, Crino P, Eberwine J (2000) Stimulation of glutamate receptor protein synthesis and membrane insertion within isolated neuronal dendrites. Proc Natl Acad Sci USA 97:11545-11550

64. Grooms SY, Noh KM, Regis R, Bassell GJ, Bryan MK, Carroll RC, Zukin RS (2006) Activity bidirectionally regulates AMPA receptor mRNA abundance in dendrites of hippocampal neurons. J Neurosci 26:8339-8351

65. Boncompain G, Perez F (2012) Synchronizing protein transport in the secretory pathway. Curr Protoc Cell Biol. https://doi. org/10.1002/0471143030.cb1519s57

66. Boncompain G, Perez F (2014) Synchronization of secretory cargos trafficking in populations of cells. Methods Mol Biol 1174:211-223

67. Martin S, Nishimune A, Mellor JR, Henley JM (2007) SUMOylation regulates kainate-receptor-mediated synaptic transmission. Nature 447:321-325

68. Martin S, Bouschet T, Jenkins EL, Nishimune A, Henley JM (2008) Bidirectional regulation of kainate receptor surface expression in hippocampal neurons. J Biol Chem 283:36435-36440

69. Konopacki FA, Jaafari N, Rocca DL, Wilkinson KA, Chamberlain S, Rubin P, Kantamneni S, Mellor JR, Henley JM (2011) Agonist-induced PKC phosphorylation regulates GluK2 SUMOylation and kainate receptor endocytosis. Proc Natl Acad Sci USA 108:19772-19777

70. González-González IM, Konopaki F, Rocca DL, Doherty AJ, Jaafari N, Wilkinson KA, Henley JM (2012) Kainate receptor trafficking. WIRES Membr Transp Signal 1:31-44

71. Copits BA, Swanson GT (2013) Kainate receptor post-translational modifications differentially regulate association with $4.1 \mathrm{~N}$ to control activity-dependent receptor endocytosis. J Biol Chem 288:8952-8965

72. Pick JE, Khatri L, Sathler MF, Ziff EB (2016) mGluR long-term depression regulates GluA2 association with COPII vesicles and exit from the endoplasmic reticulum. EMBO J. https://doi. org/10.15252/embj.201694526

73. Hanus C, Kochen L, Tom Dieck S, Racine V, Sibarita JB, Schuman EM, Ehlers MD (2014) Synaptic control of secretory trafficking in dendrites. Cell Rep 7:1771-1778

74. Vivithanaporn P, Yan S, Swanson GT (2006) Intracellular trafficking of KA2 kainate receptors mediated by interactions with coatomer protein complex I (COPI) and 14-3-3 chaperone systems. J Biol Chem 281:15475-15484

75. Nasu-Nishimura Y, Jaffe H, Isaac JT, Roche KW (2010) Differential regulation of kainate receptor trafficking by phosphorylation of distinct sites on GluR6. J Biol Chem 285:2847-2856

76. Yan D, Yamasaki M, Straub C, Watanabe M, Tomita S (2013) Homeostatic control of synaptic transmission by distinct glutamate receptors. Neuron 78:687-699

77. Straub C, Noam Y, Nomura T, Yamasaki M, Yan D, Fernandes HB, Zhang P, Howe JR, Watanabe M, Contractor A, Tomita S (2016) Distinct subunit domains govern synaptic stability and specificity of the kainate receptor. Cell Rep 16:531-544

78. Fernandes HB, Catches JS, Petralia RS, Copits BA, Xu J, Russell TA, Swanson GT, Contractor A (2009) High-affinity kainate receptor subunits are necessary for ionotropic but not metabotropic signaling. Neuron 63:818-829

79. Mulle C, Sailer A, Perez-Otano I, Dickinson-Anson H, Castillo PE, Bureau I, Maron C, Gage FH, Mann JR, Bettler B, Heinemann SF (1998) Altered synaptic physiology and reduced susceptibility to kainate- induced seizures in GluR6-deficient mice. Nature 392:601-605

80. Fievre S, Carta M, Chamma I, Labrousse V, Thoumine O, Mulle C (2016) Molecular determinants for the strictly compartmentalized expression of kainate receptors in CA3 pyramidal cells. Nat Commun 7:12738

81. Coussen F, Normand E, Marchal C, Costet P, Choquet D, Lambert M, Mege RM, Mulle C (2002) Recruitment of the kainate receptor subunit glutamate receptor 6 by cadherin/catenin complexes. J Neurosci 22:6426-6436

82. Garcia EP, Mehta S, Blair LA, Wells DG, Shang J, Fukushima T, Fallon JR, Garner CC, Marshall J (1998) SAP90 binds and clusters kainate receptors causing incomplete desensitization. Neuron 21:727-739

83. Hirbec H, Francis JC, Lauri SE, Braithwaite SP, Coussen F, Mulle C, Dev KK, Coutinho V, Meyer G, Isaac JT, Collingridge GL, Henley JM (2003) Rapid and differential regulation of AMPA and kainate receptors at hippocampal mossy fibre synapses by PICK1 and GRIP. Neuron 37:625-638

84. Ng D, Pitcher GM, Szilard RK, Sertie A, Kanisek M, Clapcote SJ, Lipina T, Kalia LV, Joo D, McKerlie C, Cortez M, Roder JC, Salter MW, McInnes RR (2009) Neto1 is a novel CUB-domain NMDA receptor-interacting protein required for synaptic plasticity and learning. PLoS Biol 7:e41

85. Bowie D, Garcia EP, Marshall J, Traynelis SF, Lange GD (2003) Allosteric regulation and spatial distribution of kainate receptors bound to ancillary proteins. J Physiol 547:373-385

86. Suzuki E, Kamiya H (2016) PSD-95 regulates synaptic kainate receptors at mouse hippocampal mossy fiber-CA3 synapses. Neurosci Res 107:14-19

87. Carta M, Opazo P, Veran J, Athane A, Choquet D, Coussen F, Mulle C (2013) CaMKII-dependent phosphorylation of GluK5 mediates plasticity of kainate receptors. EMBO J 32:496-510

88. Matsuda K (2017) Synapse organization and modulation via C1q family proteins and their receptors in the central nervous system. Neurosci Res 116:46-53

89. Matsuda K, Budisantoso T, Mitakidis N, Sugaya Y, Miura E, Kakegawa W, Yamasaki M, Konno K, Uchigashima M, Abe M, Watanabe I, Kano M, Watanabe M, Sakimura K, Aricescu AR, 
Yuzaki M (2016) Transsynaptic modulation of kainate receptor functions by C1q-like proteins. Neuron 90:752-767

90. Zhang W, St-Gelais F, Grabner CP, Trinidad JC, Sumioka A, Morimoto-Tomita M, Kim KS, Straub C, Burlingame AL, Howe JR, Tomita S (2009) A transmembrane accessory subunit that modulates kainate-type glutamate receptors. Neuron 61:385-396

91. Straub C, Hunt DL, Yamasaki M, Kim KS, Watanabe M, Castillo PE, Tomita S (2011) Distinct functions of kainate receptors in the brain are determined by the auxiliary subunit Neto1. Nat Neurosci 14:866-873

92. Copits BA, Swanson GT (2012) Dancing partners at the synapse: auxiliary subunits that shape kainate receptor function. Nat Rev Neurosci 13:675-686

93. Tomita S, Castillo PE (2012) Neto1 and Neto2: auxiliary subunits that determine key properties of native kainate receptors. J Physiol 590:2217-2223

94. Howe JR (2014) Modulation of non-NMDA receptor gating by auxiliary subunits. J Physiol. https://doi.org/10.1113/ jphysiol.2014.273904

95. Han L, Howe JR, Pickering DS (2016) Neto2 influences on kainate receptor pharmacology and function. Basic Clin Pharmacol Toxicol 119:141-148

96. Wyeth MS, Pelkey KA, Yuan X, Vargish G, Johnston AD, Hunt S, Fang C, Abebe D, Mahadevan V, Fisahn A, Salter MW, McInnes RR, Chittajallu R, McBain CJ (2017) Neto auxiliary subunits regulate interneuron somatodendritic and presynaptic kainate receptors to control network inhibition. Cell Rep 20:2156-2168

97. Tang M, Pelkey KA, Ng D, Ivakine E, McBain CJ, Salter MW, McInnes RR (2011) Neto1 is an auxiliary subunit of native synaptic kainate receptors. J Neurosci 31:10009-10018

98. Wyeth MS, Pelkey KA, Petralia RS, Salter MW, McInnes RR, McBain CJ (2014) Neto auxiliary protein interactions regulate kainate and NMDA receptor subunit localization at mossy fiberCA3 pyramidal cell synapses. J Neurosci 34:622-628

99. Tang M, Ivakine E, Mahadevan V, Salter MW, McInnes RR (2012) Neto2 interacts with the scaffolding protein GRIP and regulates synaptic abundance of kainate receptors. PLoS ONE 7:e51433

100. Palacios-Filardo J, Aller MI, Lerma J (2016) Synaptic targeting of kainate receptors. Cereb Cortex 26:1464-1472

101. Copits BA, Robbins JS, Frausto S, Swanson GT (2011) Synaptic targeting and functional modulation of GluK1 kainate receptors by the auxiliary neuropilin and tolloid-like (NETO) proteins. J Neurosci 31:7334-7340

102. Sheng N, Shi YS, Nicoll RA (2017) Amino-terminal domains of kainate receptors determine the differential dependence on Neto auxiliary subunits for trafficking. Proc Natl Acad Sci USA. https://doi.org/10.1073/pnas.1619253114

103. Paternain AV, Herrera MT, Nieto MA, Lerma J (2000) GluR5 and GluR6 kainate receptor subunits coexist in hippocampal neurons and coassemble to form functional receptors. J Neurosci 20:196-205

104. Salinas GD, Blair LA, Needleman LA, Gonzales JD, Chen Y, Li M, Singer JD, Marshall J (2006) Actinfilin is a Cul3 substrate adaptor, linking GluR6 kainate receptor subunits to the ubiquitinproteasome pathway. J Biol Chem 281:40164-40173

105. Maraschi A, Ciammola A, Folci A, Sassone F, Ronzitti G, Cappelletti G, Silani V, Sato S, Hattori N, Mazzanti M, Chieregatti E, Mulle C, Passafaro M, Sassone J (2014) Parkin regulates kainate receptors by interacting with the GluK2 subunit. Nat Commun 5:5182

106. Pickering DS, Taverna FA, Salter MW, Hampson DR (1995) Palmitoylation of the GluR6 kainate receptor. Proc Natl Acad Sci USA 92:12090-12094
107. Wilkinson KA, Konopacki F, Henley JM (2012) Modification and movement: phosphorylation and SUMOylation regulate endocytosis of GluK2-containing kainate receptors. Commun Integr Biol 5:223-226

108. Wilkinson KA, Henley JM (2010) Mechanisms, regulation and consequences of protein SUMOylation. Biochem J 428:133-145

109. Finley D, Chau V (1991) Ubiquitination. Annu Rev Cell Biol 7:25-69

110. Chittajallu R, Vignes M, Dev KK, Barnes JM, Collingridge GL, Henley JM (1996) Regulation of glutamate release by presynaptic kainate receptors in the hippocampus. Nature 379:78-81

111. Kamiya H, Ozawa S (1998) Kainate receptor-mediated inhibition of presynaptic $\mathrm{Ca}^{2+}$ influx and EPSP in area CA1 of the rat hippocampus. J Physiol 509(Pt 3):833-845

112. Frerking M, Schmitz D, Zhou Q, Johansen J, Nicoll RA (2001) Kainate receptors depress excitatory synaptic transmission at $\mathrm{CA} 3 \rightarrow$ CA1 synapses in the hippocampus via a direct presynaptic action. J Neurosci 21:2958-2966

113. Schmitz D, Mellor J, Frerking M, Nicoll RA (2001) Presynaptic kainate receptors at hippocampal mossy fiber synapses. Proc Natl Acad Sci USA 98:11003-11008

114. Rodriguez-Moreno A, Sihra TS (2011) Metabotropic actions of kainate receptors in the control of glutamate release in the hippocampus. Adv Exp Med Biol 717:39-48

115. Andrade-Talavera Y, Duque-Feria P, Sihra TS, RodriguezMoreno A (2013) Pre-synaptic kainate receptor-mediated facilitation of glutamate release involves PKA and $\mathrm{Ca}(2+)$-calmodulin at thalamocortical synapses. J Neurochem 126:565-578

116. Castillo PE, Janz R, Sudhof TC, Tzounopoulos T, Malenka RC, Nicoll RA (1997) Rab3A is essential for mossy fibre long-term potentiation in the hippocampus. Nature 388:590-593

117. Melyan Z, Wheal HV, Lancaster B (2002) Metabotropic-mediated kainate receptor regulation of IsAHP and excitability in pyramidal cells. Neuron 34:107-114

118. Melyan Z, Lancaster B, Wheal HV (2004) Metabotropic regulation of intrinsic excitability by synaptic activation of kainate receptors. J Neurosci 24:4530-4534

119. Rodriguez-Moreno A, Lerma J (1998) Kainate receptor modulation of GABA release involves a metabotropic function. Neuron 20:1211-1218

120. Jiang L, Kang D, Kang J (2015) Potentiation of tonic GABAergic inhibition by activation of postsynaptic kainate receptors. Neuroscience 298:448-454

121. Chamma I, Chevy Q, Poncer JC, Levi S (2012) Role of the neuronal $\mathrm{K}-\mathrm{Cl}$ co-transporter $\mathrm{KCC} 2$ in inhibitory and excitatory neurotransmission. Front Cell Neurosci 6:5

122. Woodin MA, Ganguly K, Poo MM (2003) Coincident preand postsynaptic activity modifies GABAergic synapses by postsynaptic changes in $\mathrm{Cl}-$ transporter activity. Neuron 39:807-820

123. Tyzio R, Nardou R, Ferrari DC, Tsintsadze T, Shahrokhi A, Eftekhari S, Khalilov I, Tsintsadze V, Brouchoud C, Chazal G, Lemonnier E, Lozovaya N, Burnashev N, Ben-Ari Y (2014) Oxytocin-mediated GABA inhibition during delivery attenuates autism pathogenesis in rodent offspring. Science 343:675-679

124. Woo NS, Lu J, England R, McClellan R, Dufour S, Mount DB, Deutch AY, Lovinger DM, Delpire E (2002) Hyperexcitability and epilepsy associated with disruption of the mouse neuronalspecific K-Cl cotransporter gene. Hippocampus 12:258-268

125. Ivakine EA, Acton BA, Mahadevan V, Ormond J, Tang M, Pressey JC, Huang MY, Ng D, Delpire E, Salter MW, Woodin MA, McInnes RR (2013) Neto2 is a KCC2 interacting protein required for neuronal Cl- regulation in hippocampal neurons. Proc Natl Acad Sci USA 110:3561-3566 
126. Mahadevan V, Pressey JC, Acton BA, Uvarov P, Huang MY, Chevrier J, Puchalski A, Li CM, Ivakine EA, Airaksinen MS, Delpire E, McInnes RR, Woodin MA (2014) Kainate receptors coexist in a functional complex with $\mathrm{KCC} 2$ and regulate chloride homeostasis in hippocampal neurons. Cell Rep 7:1762-1770

127. Matute C (2011) Therapeutic potential of kainate receptors. CNS Neurosci Ther 17:661-669

128. Yuan H, Low CM, Moody OA, Jenkins A, Traynelis SF (2015) Ionotropic GABA and glutamate receptor mutations and human neurologic diseases. Mol Pharmacol 88:203-217

129. Crepel V, Mulle C (2015) Physiopathology of kainate receptors in epilepsy. Curr Opin Pharmacol 20:83-88

130. Tauck DL, Nadler JV (1985) Evidence of functional mossy fiber sprouting in hippocampal formation of kainic acid-treated rats. J Neurosci 5:1016-1022

131. Represa A, Trembley E, Ben-Ari Y (1987) Kainate binding sites in the hippocampal mossy fibres: localization and plasticity. Neuroscience 20:739-748

132. Epsztein J, Represa A, Jorquera I, Ben-Ari Y, Crepel V (2005) Recurrent mossy fibers establish aberrant kainate receptor-operated synapses on granule cells from epileptic rats. J Neurosci 25:8229-8239

133. Peret A, Christie LA, Ouedraogo DW, Gorlewicz A, Epsztein J, Mulle C, Crepel V (2014) Contribution of aberrant GluK2containing kainate receptors to chronic seizures in temporal lobe epilepsy. Cell Rep 8:347-354

134. Yu LM, Polygalov D, Wintzer ME, Chiang MC, McHugh TJ (2016) CA3 synaptic silencing attenuates kainic acid-induced seizures and hippocampal network oscillations. eNeuro. https:// doi.org/10.1523/ENEURO.0003-16.2016

135. Guzman YF, Ramsey K, Stolz JR, Craig DW, Huentelman MJ, Narayanan V, Swanson GT (2017) A gain-of-function mutation in the GRIK2 gene causes neurodevelopmental deficits. Neurol Genet 3:e129
136. Lanore F, Labrousse VF, Szabo Z, Normand E, Blanchet C, Mulle C (2012) Deficits in morphofunctional maturation of hippocampal mossy fiber synapses in a mouse model of intellectual disability. J Neurosci 32:17882-17893

137. Micheau J, Vimeney A, Normand E, Mulle C, Riedel G (2014) Impaired hippocampus-dependent spatial flexibility and sociability represent autism-like phenotypes in GluK2 mice. Hippocampus 24:1059-1069

138. Griswold AJ, Ma D, Cukier HN, Nations LD, Schmidt MA, Chung RH, Jaworski JM, Salyakina D, Konidari I, Whitehead PL, Wright HH, Abramson RK, Williams SM, Menon R, Martin ER, Haines JL, Gilbert JR, Cuccaro ML, Pericak-Vance MA (2012) Evaluation of copy number variations reveals novel candidate genes in autism spectrum disorder-associated pathways. Hum Mol Genet 21:3513-3523

139. Aller MI, Pecoraro V, Paternain AV, Canals S, Lerma J (2015) Increased dosage of high-affinity kainate receptor gene grik4 alters synaptic transmission and reproduces autism spectrum disorders features. J Neurosci 35:13619-13628

140. Milanesi E, Bonvicini C, Congiu C, Bortolomasi M, Gainelli G, Gennarelli M, Minelli A (2015) The role of GRIK4 gene in treatment-resistant depression. Genet Res 97:e14

141. Pickard BS, Malloy MP, Christoforou A, Thomson PA, Evans KL, Morris SW, Hampson M, Porteous DJ, Blackwood DH, Muir WJ (2006) Cytogenetic and genetic evidence supports a role for the kainate-type glutamate receptor gene, GRIK4, in schizophrenia and bipolar disorder. Mol Psychiatry 11:847-857

142. Xu J, Marshall JJ, Fernandes HB, Nomura T, Copits BA, Procissi D, Mori S, Wang L, Zhu Y, Swanson GT, Contractor A (2017) Complete disruption of the kainate receptor gene family results in corticostriatal dysfunction in mice. Cell Rep 18:1848-1857 